\title{
针对肿瘤微环境精确设计的智能抗肿瘤 纳米药物
}

王婧 ${ }^{1}$, 聂广军 $^{1^{*}}$, 赵宇亮 ${ }^{1}$, 陈学思 ${ }^{*}$

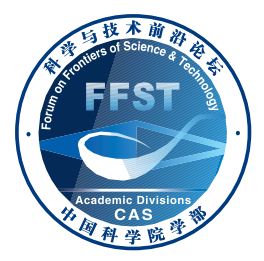

1. 国家纳米科学中心, 中国科学院纳米生物效应与安全性重点实验室, 北京 100190;

2. 中国科学院长春应用化学研究所, 长春 130022

*联系人, E-mail: niegj@nanoctr.cn; xschen@ciac.ac.cn

2021-04-06 收稿, 2021-06-18 修回, 2021-07-15 接受, 2021-07-21 网络版发表

国家重点研发计划(2018YFE0205300，2018YFA0208900)和王宽诚教育基金会项目(GJTD-2018-03)资助

摘要 肿瘤微环境调控概念的兴起极大推进了智能纳米药物的发展. 作为治疗或递药靶点, 基质和血管等微环境 成分在基因层面上较肿瘤细胞更稳定, 并且提供了在递药过程中绕过部分生物屏障的可能. 我们的研究表明, 充分 利用纳米材料的固有优势和功能化潜力, 针对肿瘤微环境精确设计纳米药物, 对于开发和实现新的纳米抗肿瘤策 略至关重要. 例如, 利用高精度自组装的核酸纳米机器, 能够实现强效凝血分子在血液循环中的安全递送; 利用多 重释药的纳米结构局域性清除肿瘤相关血小板, 可提高纳米药物穿透肿瘤血管内皮屏障的效率等. 基于以上学术 思想, 近年来, 我们系统研究了针对不同微环境成分或病理状态的靶向调控策略, 利用智能纳米药物实现了包括肿 瘤血管特异性栓塞、肿瘤基质微环境重塑、肿瘤血管通透性增强等创新性微环境调控方案. 本文综述了其中的代 表性进展, 讨论了相关智能纳米体系在肿瘤微环境调控中的潜力和局限, 并分析了智能抗肿瘤纳米药物的未来发 展方向.

关键词肿瘤微环境, 纳米医学, 靶向递送, 纳米机器人, 生物屏障

利用纳米材料作为药物载体，是目前抗肿瘤药物 研发最活跃的方向之一. 作为新一代药物递送体系, 纳 米结构具有的可控自组装、多功能和智能化修饰等特 点, 使它们表现出许多不同于传统剂型的新性质和新 功能. 纳米递送可以有效改善传统药物的药剂学性质 (如溶解性、稳定性等), 优化其药代动力学参数和体内 分布, 降低体内毒性; 通过对载体进行适当修饰, 还可 实现主动靶向、响应性释药等功能. 目前, 世界范围内 已有数十种抗肿瘤纳米药物进人市场或临床试验阶

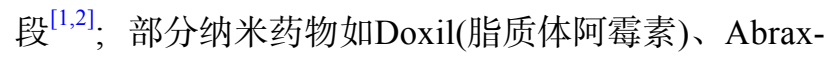
ane(白蛋白紫杉醇)等已在临床广泛应用并取得了商业
成功.

尽管抗肿瘤纳米药物展现出巨大的应用前景, 但 随着相关临床经验的积累和对肿瘤病理特性研究的深 人, 科学家逐渐认识到早期纳米药物剂型在实际应用 中仍面临诸多挑战 ${ }^{[3,4]}$. 例如, 肿瘤的复杂病理特征及 个体差异使我们难以找到高特异性的单一递送靶点; 体内和瘤内的多重生物屏障严重影响靶向递药效率; 复杂的纳米载体及纳米-生物相互作用使得纳米药物 体内行为难以精确控制等. 另外, 早期将小分子化疗药 物包载人纳米载体的设计思路, 无法突破传统药物的 耐药性等问题. 因此, 尽管目前进人临床研究的纳米药

引用格式: 王婧, 聂广军, 赵宇亮, 等. 针对肿瘤微环境精确设计的智能抗肿瘤纳米药物. 科学通报, 2021, 66: 4608-4618 Wang J, Nie G J, Zhao Y L, et al. Precisely designed nanotherapeutics for microenvironment-targeted cancer therapy (in Chinese). Chin Sci Bull, 2021, 66: 4608-4618, doi: 10.1360/TB-2021-0340 
物仍以脂质体、聚合物胶束、无机纳米颗粒、白蛋白 复合物等简单剂型为主 ${ }^{[2]}$, 但前沿纳米医学研究已开始 重视充分发挥纳米材料在可设计性方面的优势. 根据 不同肿瘤的病生理特征，针对性设计多重靶向、多步 骤响应、联合治疗、诊疗一体化等功能集成体系，以 求更精细地应对复杂体内和瘤内环境提出的挑战. 新 一代的“智能化”纳米药物递送体系可能主动穿越各种 生理屏障，如血脑、血眼、血胸腺、皮肤与黏膜、网 状内皮系统、血睪、胎盘等, 并通过配体识别、 $\mathrm{pH}$ 、 电荷等病灶响应，或结合光照、超声、磁导向等体外 操控技术, 达到靶向递送和精确控释的目的.

肿瘤微环境调控概念的兴起极大推进了多功能纳 米药物的发展. 肿瘤微环境主要包括肿瘤部位的基质 细胞、免疫细胞、血管系统、淋巴系统及细胞外基质 成分，它们共同构成了肿瘤生长的“土壤”. 受到肿瘤细 胞分泌的信号分子调控，微环境细胞不仅分泌多种生 长因子、细胞因子、趋化因子等促进肿瘤细胞的增殖 和转移, 而且往往是诱导肿瘤细胞对传统疗法产生耐 药的“帮凶”, ${ }^{[5,6]}$. 另一方面, 肿瘤微环境呈现出许多与正 常组织不同的特点, 如低氧、微酸性、基质纤维化、 血管生成因子优势、血液高凝状态、免疫抑制等，部 分肿瘤相关的微环境细胞也有独特抗原表达. 这些特 征为靶向调控微环境, 针对性抑制或逆转其对肿瘤生 长的促进作用提供了基础. 作为治疗或递药靶点, 基质 和血管等微环境成分在基因层面上较肿瘤细胞更稳定, 相对不易产生耐药 ${ }^{[5]}$; 递药过程中需要穿过的屏障也较 少. 因此, 在深人了解肿瘤微环境特点的基础上，探索 基于微环境调控的智能纳米药物设计，对新一代纳米 药物研发有重大价值.

基于以上学术思想，近年来本团队系统研究了针 对不同微环境成分的靶向调控策略, 提出了一系列创 新性的纳米药物精确设计思路. 本文将简单综述其中 的代表性进展, 并对该领域的未来发展提出展望.

\section{1 高精度组装“纳米机器”实现肿瘤血管精确 栓塞}

肿瘤血管是肿瘤生长所需能量与养分的主要来源. 选择性栓塞肿瘤血管，能够在无需深人穿透肿瘤组织 的情况下, 大面积“饿死”肿瘤细胞, 因此相关策略一直 受到关注. 阻塞肿瘤血管作为抗癌疗法的可行性, 已由 经导管动脉化疗栓塞术(transcatheter arterial chemoembolization，TACE)在临床的成功应用初步证明. TACE
采用的是核医学影像指导下的物理栓塞，栓塞剂本身 不具备肿瘤特异性, 且当前影像技术不足以精细选择 供应肿瘤的微小血管，因此其在除肝癌外的肿瘤中的 应用受到局限 ${ }^{[7]}$. 利用纳米药物的智能递送潜力, 开发 主动靶向、智能识别肿瘤部位微小血管并原位产生阻 塞的栓塞剂，将为栓塞疗法的应用前景带来突破性的 变革. 自 1997年Thorpe研究组 ${ }^{[8]}$ 将凝血蛋白截短组织因 子利用抗体偶联的方式靶向输运至小鼠神经母细胞瘤, 已有多种基于靶向递送的肿瘤栓塞剂被报道. 其中, 大 部分研究致力于将截短组织因子与靶向配体共价连接 或融合表达，在动物模型中取得了明显的治疗效 果 ${ }^{[9 \sim 11]}$. 然而, 我们前期的探索表明，即使连接了靶向 基团, 凝血蛋白暴露在血液中仍有引发非特异性血栓 的风险. 这可能是该类生物栓塞剂目前临床转化进度 缓慢的原因.

近年来，一些新型纳米栓塞策略进一步拓宽了血 管栓塞剂的设计思路. Shi 研究组 ${ }^{[12]}$ 报道了一种聚合物 修饰的硅化镁 $\left(\mathrm{Mg}_{2} \mathrm{Si}\right)$ 纳米颗粒. 该纳米材料能够响应 微酸性的肿瘤微环境，释放甲硅烷并消耗肿瘤部位的 氧气供应，原位生成的二氧化硅固体在肿瘤微血管中 聚集，达到阻塞肿瘤血管的目的. Wang研究组 ${ }^{[13]}$ 最近 则构建了一种双重响应多肽纳米结构，含有模拟天然 层黏连蛋白(laminin)的片段, 分子间可形成强烈的氢键 相互作用. 静脉注射后, 纳米结构首先经由对肿瘤血管 中微血栓的靶向作用, 在肿瘤部位富集, 随后响应微酸 性环境发生构型转变, 由球形胶束重组为纤维状结构, 最终形成纤维网络堵塞血管. 这些结果都显示了巧妙 设计的纳米体系在智能血管栓塞药物开发中的重要潜 力. 与前文讨论的生物栓塞剂相比, 这些新型纳米血管 栓塞剂不会引发天然凝血机制中的级联放大效应，而 主要通过纳米结构本身在肿瘤部位的累积来堵塞血管, 改善了其在血液循环中的安全性，但另一方面也可能 降低引发局部血栓的效率. 更强的局部凝血反应和安 全的外周循环递送能否兼得，仍是血管栓塞治疗研究 面对的重要难题.

我们的研究表明，基于DNA精确自组装的纳米机 器人技术有可能解决强力生物栓塞剂的安全递送问题. 具体地, 利用近年来快速发展的DNA折纸术, 设计并制 备了一种选择性响应肿瘤血管的纳米机器(图1), 用于 强效促凝分子凝血酶的靶向递送和响应释放 ${ }^{[14]}$. 通过 精确的分子结构设计和程序化的自组装方法，4个凝血 酶分子(经过表面DNA修饰)被定点、定量组装到长方 
(a)
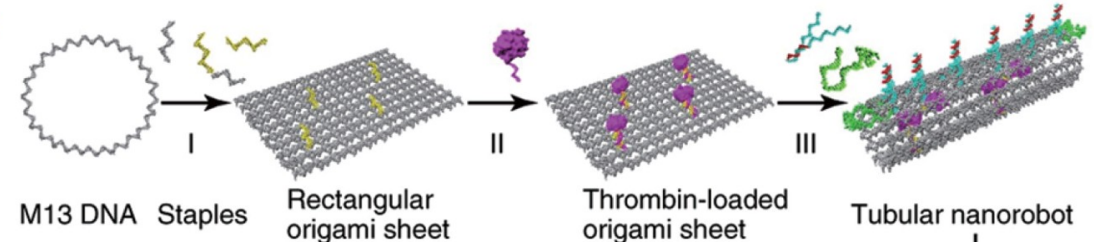

Thrombin-loaded
origami sheet

Tubular nanorobot

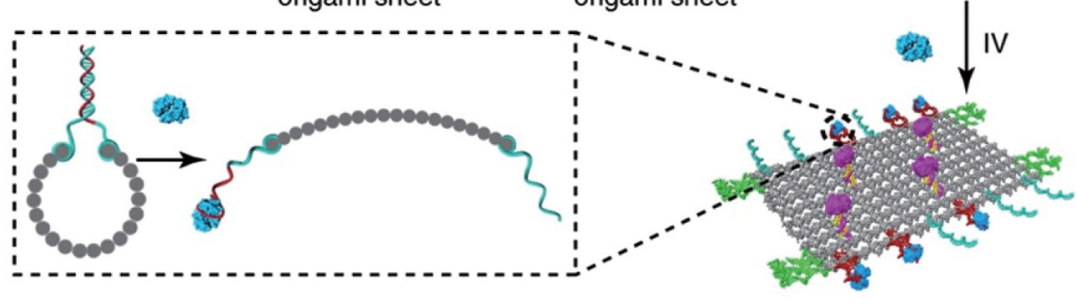

Open state of nanorobot

(b)
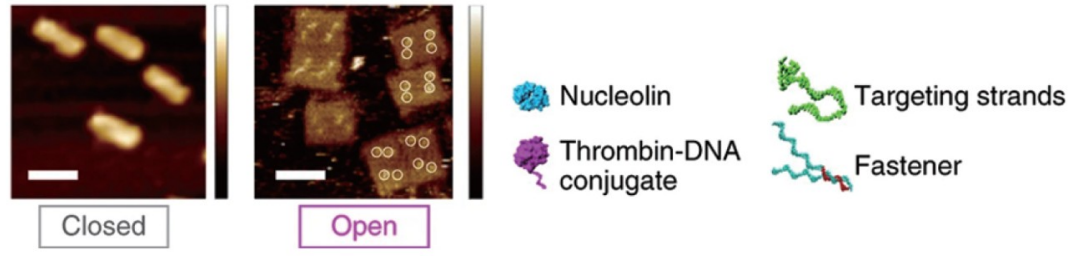

(c)

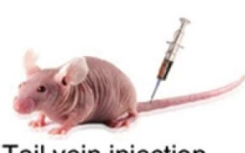

Before treatment
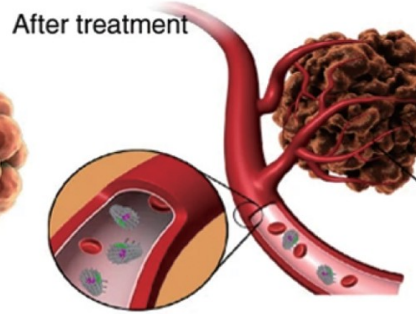

Tumor tissue necrosis

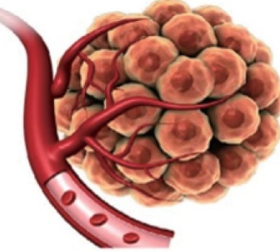

(a) 纳米机器人的设计和结构. (b) 不同状态下纳米机器人的原子力显微镜

图 1 (网络版彩色)肿瘤血管响应的凝血酶递送DNA纳米机器人 ${ }^{[14]}$. (a) 纳米机器人的设计和结构.
照片. (c) 纳米机器人在体内引起肿瘤血管栓塞的机制. Copyright (C) 2018, Nature Publishing Group

Figure 1 (Color online) DNA nanorobots for tumor vasculature-reponsive thrombin delivery ${ }^{[14]}$. (a) Material design and structure of DNA nanorobots. (b) Atomic force microscopic images of nanorobots in different states. (c) Schematic illustration of nanorobots causing tumor-specific vascular occlusion. Copyright (C) 2018, Nature Publishing Group

形DNA片层上. 随后DNA分子锁将长方形卷曲成长为 $90 \mathrm{~nm}$, 直径约为 $19 \mathrm{~nm}$ 的管状结构. 由于核酸分子基于 碱基配对的自组装行为具有极高的可控性和可重复性, 因此成品纳米机器的微观结构和其中凝血酶装载的相 对位置均有很高的空间精度, 保证了凝血酶被准确包 裹在管腔中, 不会引发非特异性凝血. 到达肿瘤微环境 后，DNA分子锁通过核酸适配体AS1411，对肿瘤血管 内皮标志物核仁素蛋白产生分子识别, 发生构型变化 后导致结构开启, 凝血酶暴露在肿瘤血管系统中, 快速 引发局部血栓. 动物实验证明, 新型DNA纳米机器人对 乳腺癌(MDA-MB-231)、黑色素瘤(B16-F10)、卵巢癌 (SK-OV3)小鼠皮下接种模型和TetO-Kras ${ }^{G 12 D}$ 转基因小 鼠原发肺癌模型均有显著的治疗效果. 其中, 在血管相
对丰富的乳腺癌和黑色素瘤皮下模型中, 肿瘤(体积)抑 制率分别超过了 $80 \%$ 和 $90 \%$. 纳米机器人在小鼠和巴马 小型猪模型中也体现出良好的生物安全性和免疫惰性, 尤其是在治疗所用等效剂量下, 未观察到对动物凝血 指标造成任何影响. 本研究不仅是DNA折纸结构用于 哺乳动物体内疾病治疗, 更是实现了凝血酶这一强效 促凝剂的静脉递送. 目前, DNA折纸结构较高的制备 成本和放大生产难度仍是该策略向临床转化的障碍, 但由于核酸生物合成技术的快速发展，复杂DNA纳米 材料的造价已在逐步下降 ${ }^{[15]}$. 因此我们相信, 随着生产 工艺的持续改进, 基于DNA折纸技术的纳米机器药物 将有更加广阔的应用前景.

另外, 该结果还提示, 利用纳米材料自身的特性和 
优势, 可以将原本无法作为药物使用的生物活性分子 制成药物, 为纳米药物突破已有抗肿瘤药物的限制提 供可能. 该研究人选“2018年中国十大科技进展”.

\section{2 功能集成纳米药物重塑肿瘤基质微环境}

肿瘤基质是血管系统之外肿瘤微环境的另一主要 成分, 由基质细胞(如成纤维细胞)与它们分泌的胶原、 纤连蛋白、金属蛋白酶等细胞外基质成分(extra cellular matrix, ECM)组成. 与健康组织中的“静息” 状态相 比, 肿瘤微环境中的基质细胞处于活化状态, 其分泌的 多种生长因子、细胞因子等对肿瘤生长、侵袭、免疫 逃逸和产生耐药起到重要作用 ${ }^{[16]}$. 此外, 活化的基质细 胞分泌的细胞外基质高度纤维化, 构成致密的结缔组 织“屏障”, 使药物难以透过, 严重影响治疗效果. 以基 质增生最为突出的癌症类型之一胰腺癌为例, 目前临 床实践中可用药物极少, 预后极差, 且现有化疗方法 (基于吉西他滨的化疗) 对病人生存期只有微弱提 升 $^{[17,18]}$.

目前存在三类主要的肿瘤基质调控策略 ${ }^{[16]}$ :(1) 靶 向细胞外基质，如促进纤维化成分降解、抑制细胞外 基质合成等; (2) 靶向基质细胞, 如清除肿瘤相关成纤 维细胞或抑制其活性等; (3) 靶向促基质活化的信号通 路, 如拮抗相关细胞因子等. 这些方法均能在一定程度 上缓解肿瘤部位的基质增生现象, 增加药物瘤内渗透. 本团队 ${ }^{[19]}$ 的前期工作也证明, 将化疗药物靶向输运到 肿瘤相关成纤维细胞, 清除基质屏障, 能够显著改善纳 米药物向瘤内的递送效率. 然而, 近年来一些研究指出, 在胰腺癌等基质特别丰富的肿瘤中, 大量清除基质成 分之后, 由于组织稳态遭到破坏, 残余的肿瘤细胞往往 更易转移或转化为更恶性的表型 ${ }^{[20,21]}$. 鉴于基质占胰 腺癌组织比例常高达 $90 \%$, 是化疗方案实施的重大障 碍, 发展温和、安全、高效的胰腺癌基质调控策略无 疑对胰腺癌的治疗有重要意义.

目前报道了多种药物可以温和地抑制基质细胞. 例如, 抑制脯氨酸-4-差化酶( $\mathrm{P} 4 \mathrm{H})$ 等合成胶原成分必须 的蛋白 ${ }^{[22,23]}$, 其能够使基质细胞减少分泌细胞外基质, 减轻肿瘤组织的纤维化程度. 将抗纤维化的药物, 如吡 非尼酮(pirfenidone) $)^{[24]}$ 或槲皮素(quercetin) ${ }^{[25]}$ 递送到肿 瘤组织, 也能够暂时降低基质细胞的活化水平. 不过, 由于这些药物只是部分、暂时抑制活化基质细胞的促 肿瘤功能, 因此使用时仍易有效果不足, 或者必须持续 给药才能维持效果的问题.
本才团队 ${ }^{[26]}$ 针对胰腺癌的病理特征, 设计了一种多 层次响应型纳米药物载体, 用于诱导胰腺癌微环境的 主要基质细胞——胰腺星状细胞(pancreatic stellate cells, PSCs)重返静息状态, 从而在避免杀伤基质细胞 的同时, 更全面地调控肿瘤基质微环境. 该体系为表面 修饰接枝共聚物的金纳米粒. 聚合物外层为可延长循 环时间的聚乙二醇(PEG), 内层的聚乙烯亚胺(PEI)通过 静电吸附包载两种星状细胞调控药物: 促使细胞“静 息”的全反式维甲酸(ATRA)及抑制纤维化成分分泌的 热休克蛋白47(HSP47)siRNA. 由于接枝共聚物中引入 了 $\mathrm{pH}$ 响应键, 智能纳米药物可在进人呈微酸性的肿瘤 微环境时脱除PEG外壳, 暴露出带正电的强穿透力内 核进入星状细胞(图2). 实验表明, 该纳米药物作用于 胰腺星状细胞时, 不仅能显著抑制星状细胞活化状 态、减少细胞外基质的合成, 而且能够诱导星状细胞 转化为静息表型. 在动物模型中, 纳米药物能够有效逆 转星状细胞的活化, 降低肿瘤组织纤维化程度; 在此基 础上合并吉西他滨化疗, 可显著提升化疗效果. 与单独 使用一种药物相比, 两种基质调控药物联合递送的抗 纤维化效果显著加强. 该温和调控策略无需杀伤基质 细胞, 避免了传统基质清除策略的隐患. 同时, 通过“重 塑”基质微环境与肿瘤细胞的相互作用, 系统性地抑制 了其对治疗的不利影响. 另一方面, 我们也注意到, 这 种调控策略只有在合并化疗使用时, 方能表现出明显 的抗肿瘤疗效 ${ }^{[26]}$. 如何优化纳米药物和小分子化疗药 物的剂量配比和给药时间, 以及能否更有效地将肿瘤 杀伤性疗法和基质微环境重塑整合, 对于该策略的未 来应用仍是需要考虑的问题.

\section{3 多重释药纳米体系特异性清除肿瘤血小板 并增强瘤内血管通透性}

肿瘤血管系统在为肿瘤组织提供养分的同时, 亦 是静脉注射药物进入肿瘤的必经之路. 目前报道的绝 大多数抗肿瘤纳米药物都必须先从血管外渗至肿瘤组 织内, 方能发挥其靶向、响应等功能. 在纳米医学发展 的早期, 人们发现肿瘤组织由于血管新生过度活跃, 形 成的血管壁不完整, 渗漏性高, 内皮细胞间有较大的空 隙, 可供纳米颗粒通过. 因此提出了高通透性和滞留 (enhanced permeability and retention, EPR)效应的概念, 并将EPR介导的瘤内被动富集作为纳米载体的一大优 势 ${ }^{[3,27]}$. 但近年来的研究表明, 由于动物模型的局限、 人体复杂的生理环境、病人个体差异等因素, EPR现象 


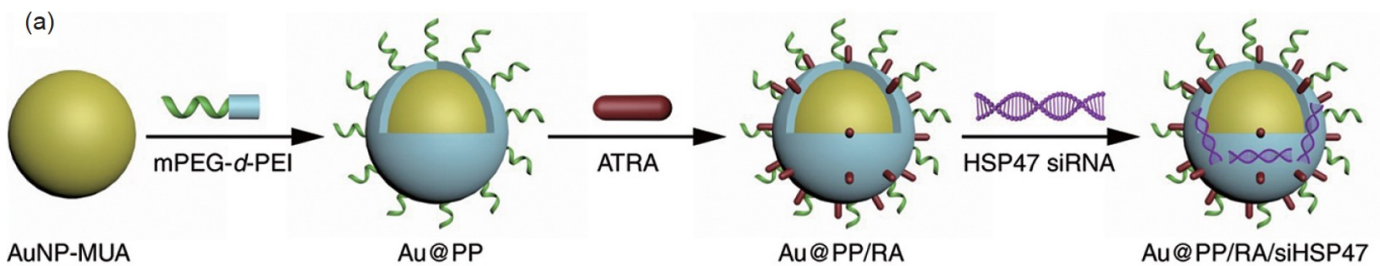

(b)

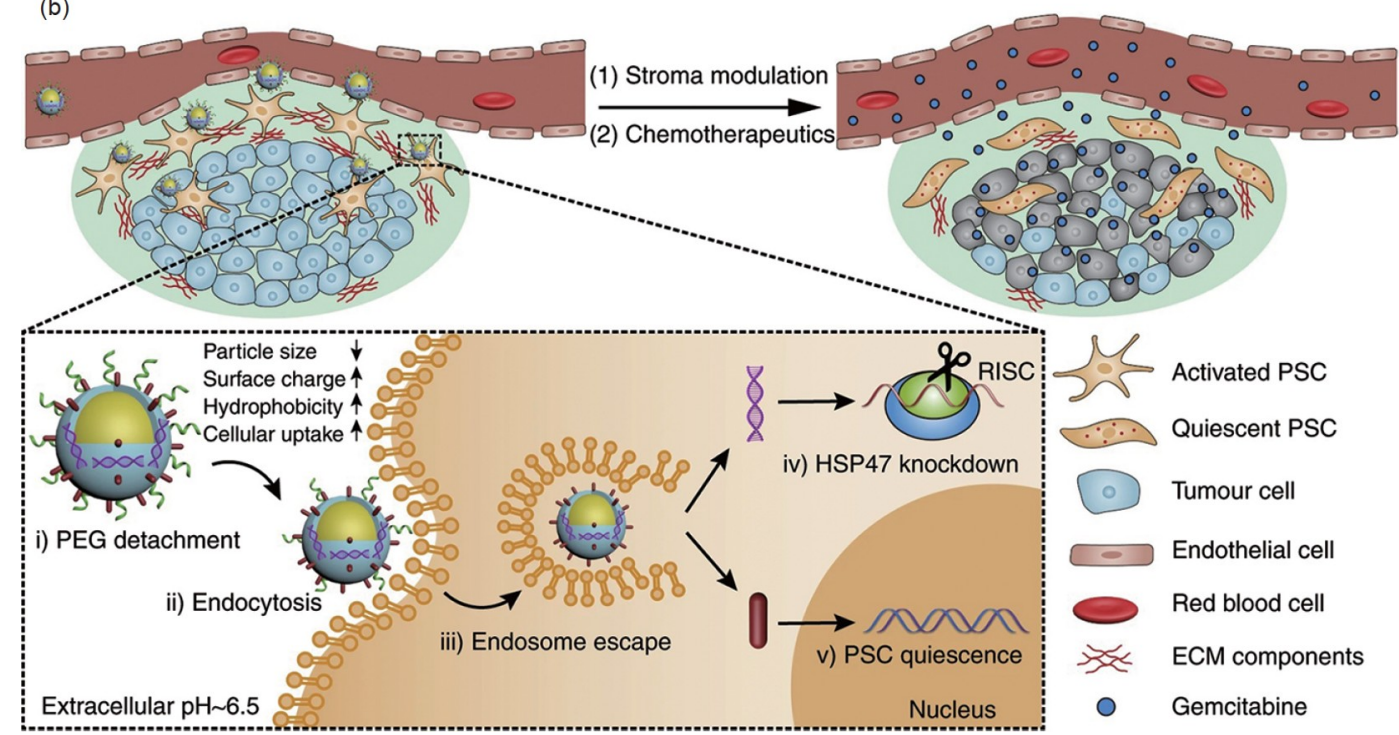

图 2 (网络版彩色)逆转胰腺星形细胞活化状态的智能纳米药物 ${ }^{[26]}$. (a) 纳米体系的构筑: 颈基十一烷酸包覆的金纳米颗粒(AuNP-MUA)经过多 重修饰，依次得到聚合物修饰的金纳米颗粒( $\mathrm{Au} @ \mathrm{PP})$ 、负载维甲酸的聚合物金纳米颗粒 $(\mathrm{Au} @ \mathrm{PP} / \mathrm{RA})$ 、同时负载维甲酸及小干扰RNA的智能 纳米药物(Au@PP/RA/siHSP47). (b) 调控肿瘤基质微环境的工作原理. Copyright C 2018, Springer Nature

Figure 2 (Color online) Using smart nanotherapeutic to reverse the activation of pancreatic stellate cells ${ }^{[26]}$. (a) Construction of the nanostructure: Gold nanoparticles capped with 11-mercaptoundecanoic acid (AuNP-MUA) were first prepared and subjected to a series of surface modification, resulting in polymer-coated nanoparticles (Au@PP), all-trans retinoic acid (ATRA)-loaded nanoparticles (Au@PP/RA) and dual-drug loaded nanoparticles (Au@PP/RA/siHSP47). (b) Working mechanisms in tumor stroma regulation. Copyright C 2018, Springer Nature

在临床表现并不明显. 例如Nichols和Bae $\mathrm{e}^{[27]}$ 在一篇综述 中指出, Doxil等脂质体药物显著延长的循环时间并未 转化为同等剂量下更好的疗效. 这提示EPR效应总体 上不足以实现纳米药物靶向递送.

近年来，已有一些研究致力于“主动”增强纳米药 物在肿瘤血管部位的外渗效率 ${ }^{[28]}$. 例如, Katayama研究 组 ${ }^{[29]}$ 和Gao研究组 ${ }^{[30]}$ 均报道了将 $\mathrm{NO}$ 供体药物靶向输运 至肿瘤血管, 利用 $\mathrm{NO}$ 气体介导的血管舒张, 能够加强 EPR效应. Tasciotti研究组 ${ }^{[31]}$ 则发现, 白细胞膜仿生修 饰能够增强纳米颗粒的外渗能力. 原因可能是白细胞 膜通过表面的淋巴细胞功能相关抗原-1(LFA-1)蛋白, 与肿瘤血管内皮细胞发生特异性黏附，加强了纳米颗 粒与内皮的相互作用 ${ }^{[32]}$. 这些进展为解决纳米药物外 渗问题提供了有益的参考. 但总体来说, 使载体高效穿 过血管内皮屏障进人肿瘤仍是纳米药物输运面临的重 要挑战.
肿瘤微环境中存在一种破坏与维护血管完整性的 动态平衡. 肿瘤组织通常处于慢性炎症状态, 招募而来 的中性粒细胞分泌的炎症因子能持续造成内皮损伤. 另一方面, 微环境中的血小板也处于部分活化状态, 它 们通过分泌 5-差色胺(5-HT)、血小板第四因子(PF-4)、 转化生长因子(TGF)- $\beta$ 等颗粒内容物或直接黏附于血 管受损处, 维持肿瘤血管内皮的完整性 ${ }^{[33]}$. 肿瘤相关血 小板的这一特殊功能为肿瘤在快速生长时仍能保持血 管系统的相对稳定提供了保障. 我们据此提出, 抑制血. 小板可以加剧肿瘤血管的内皮损伤，增强渗漏，放大 EPR效应. 鉴于全身性的血小板清除可能造成严重的 出血风险, 我们创新性地构建了一种微环境响应型多 重释药纳米药物，以实现安全、高效的肿瘤局部血小 板清除, 从而增强纳米化疗药物的外渗和瘤内递送 ${ }^{[34]}$. 体系内核为包载阿霉素的聚合物纳米颗粒，表面吸附 抗血小板抗体R300. 最外层为对微环境中基质金属蛋 
白酶MMP2具有响应性的长循环脂质体外壳, 可在抵达 肿瘤组织时脱落, 释放血小板清除抗体(图3(a)). 通过特 异清除肿瘤相关血小板，该纳米颗粒导致肿瘤血管孔 隙增大，放大EPR效应，使得包载于聚合物内核中的化 疗药物更多地进人肿瘤组织(图3(b)). 体内实验结果显 示，该纳米颗粒能够在不影响小鼠外周血小板数量和 凝血功能的情况下, 高效清除肿瘤组织内的血小板, 扫 描电子显微镜可观察到纳米颗粒介导的肿瘤血管壁裂 隙扩大现象. 与不具备血小板清除功能的纳米体系相
比，该体系显著增强了尾静脉注射 $24 \mathrm{~h}$ 后，化疗药物阿 霉素在MMP2高表达肿瘤组织内的富集,并显著改善了 治疗效果. 本研究实现了肿瘤相关血小板的安全与高 效清除，除了为纳米药物跨越血管内皮屏障提供了新 思路，也有助于我们深人理解血管和血液成分作为微 环境调控靶点的潜力. 目前, 该研究尚欠缺将血小板清 除和其他肿瘤血管通透性放大策略，例如新近报道的 通过增强内皮细胞主动转运加强纳米药物瘤内递送对 比的结果 ${ }^{[35]}$. 我们仍希望在后续研究中深入探讨这一

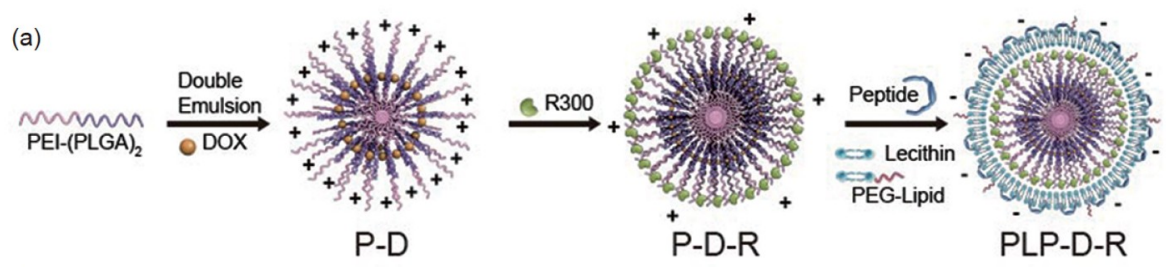

(b)

Before platelets depletion

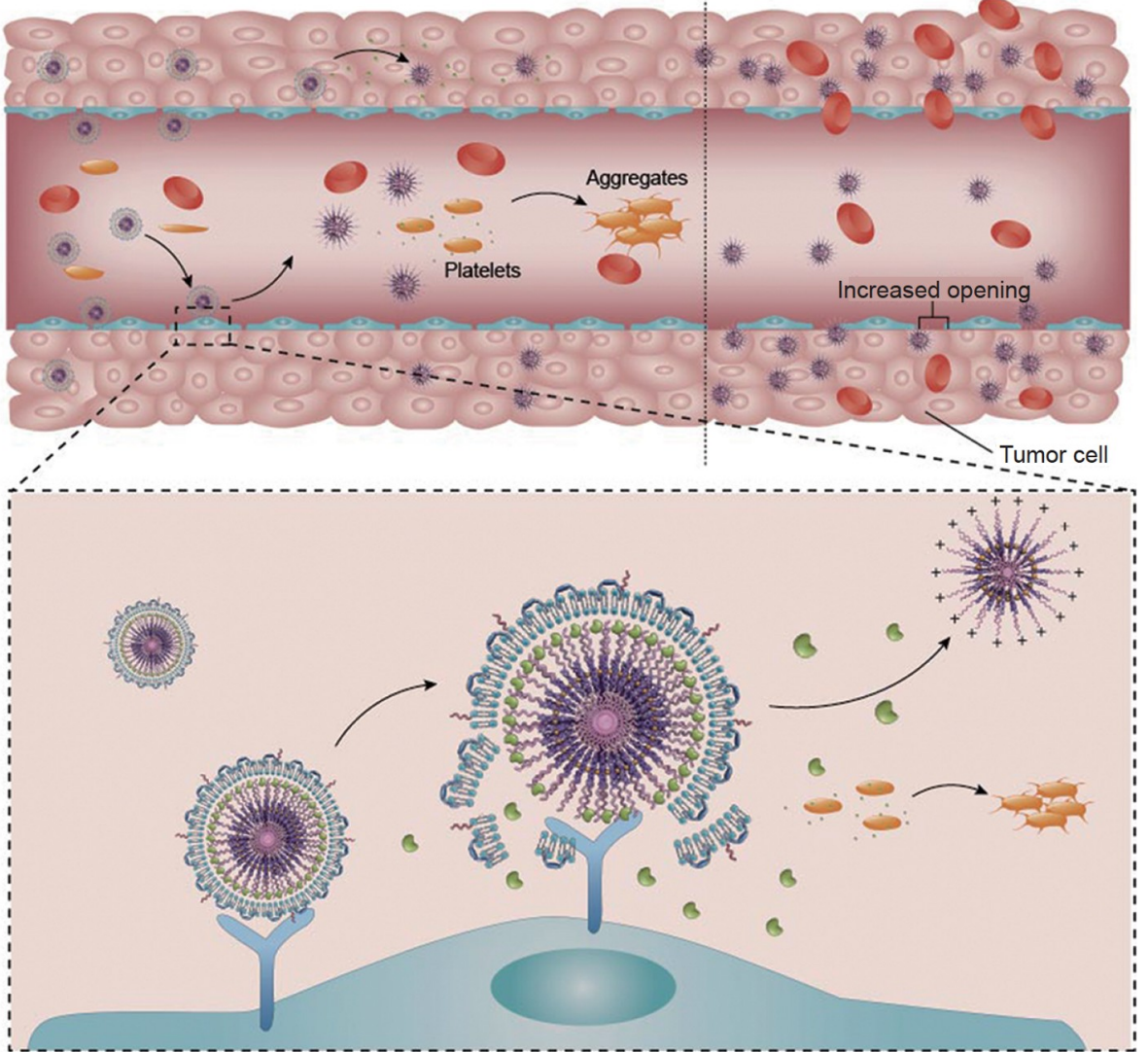

Erythrocyte

Activated platelet

Endothelial cell MMP2

图 3 (网络版彩色)智能纳米药物调控肿瘤血管EPR效应 ${ }^{[34]}$. (a) 纳米体系设计. (b) 在肿瘤微环境中的工作原理. Copyright (C) 2017, Springer Nature

Figure 3 (Color online) Using smart nanotherapeutic to modulate the enhanced permeability and retention effects of tumor vasculature ${ }^{[34]}$. (a) Material design of nanosystem. (b) Mechanism of action in the tumor microenvironment. Copyright (C) 2017, Springer Nature 
问题.

\section{4 智能调控血管微环境实现创新性化疗协同 增效}

纳米药物相对传统剂型的另一大优势是其特别适 用于联合治疗. 将针对微环境的调控手段与针对肿瘤 细胞的疗法如化疗、放疗、光疗等联用，达到协同增 效目的, 是现今微环境调控型纳米药物研究的热点. 根 据不同疗法的具体原理, 将多个治疗靶点组合起来, 设 计机制上互相补充的联合疗法，有助于我们更好地应 对肿瘤的异质性和动态进展性. 基于以上学术思想, 本 团队融近期开发了一种肿瘤靶向纳米药物，用于血管 栓塞疗法与化疗的协同治疗.

我们在前期工作中发现，生物栓塞疗法在肿瘤血 管丰富的区域效果较好，但对肿瘤边缘区域的杀伤效 力有一定局限性，有时在治疗后仍有残余肿瘤细胞导 致复发. 部分已有的生物栓塞剂研究也报道了该现 象 ${ }^{[37]}$. 研究者推测, 这可能是由于肿瘤边缘细胞可从临 近的健康组织和正常血管得到营养供给，因此对栓塞
疗法不够敏感 ${ }^{[38,39]}$. 目前生物栓塞剂与其他疗法的联 合报道较少，而且现有研究均采用不同疗法分别给药 的方式，这对优化药物配比和给药时间间隔提出了较 高的要求. 据此我们设计了一种生物相容性良好的壳 聚糖-三聚磷酸钠(TPP)纳米颗粒(图4)，表面偶联肿瘤 血管靶向肽CREKA，内部同时负载凝血酶和化疗药物 阿霉素. 由于CREKA肽段特异性与高凝性微环境中的 纤维蛋白-纤连蛋白复合物结合, 纳米颗粒在静脉给药 后能够有效靶向至肿瘤部位，而壳聚糖颗粒具有在微 酸性环境下加速释药的功能. 因此该纳米药物可在特 异性栓塞肿瘤血管的同时, 释放阿霉素进人肿瘤周边 发挥作用. 实验结果显示, 该纳米颗粒尾静脉给药后显 著富集在肿瘤部位，且在治疗剂量下不会影响小鼠的 外周凝血指标; 与单纯凝血酶治疗组相比, 联合载药的 纳米颗粒对肿瘤边缘部位的杀伤效果显著提升，并在 小鼠黑色素瘤、乳腺癌和肝癌皮下模型中都显示出更 好的总体疗效. 本工作提供了一种简单高效的生物栓 塞合并化疗方案，提示了纳米载体平台在应对肿瘤内 部复杂性方面的潜力.

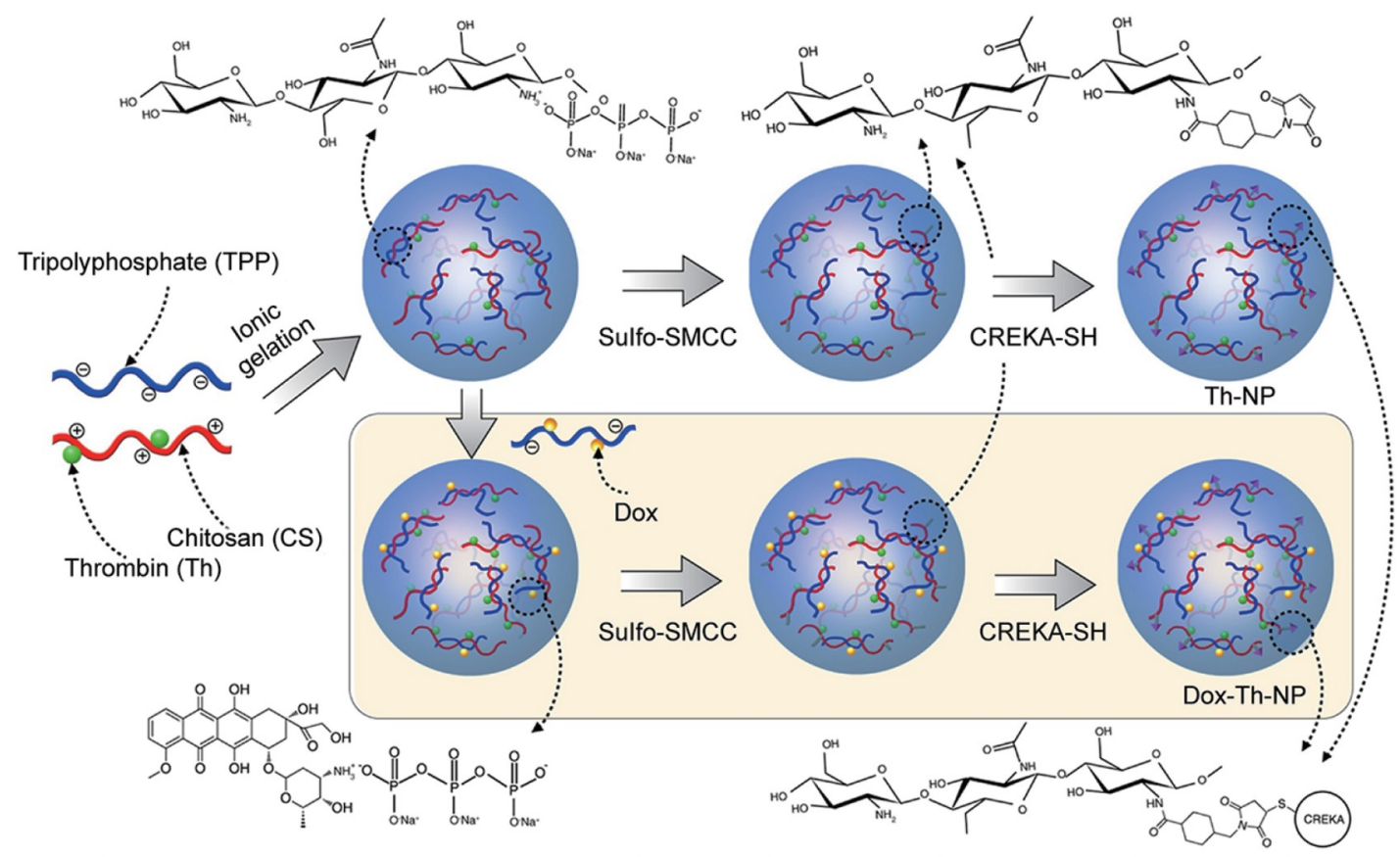

图 4 (网络版彩色)生物栓塞合并化疗的肿瘤靶向纳米药物构筑 ${ }^{[36]}$. 壳聚糖(chitosan)-三聚磷酸钠(TPP)共组装纳米颗粒通过静电吸附效应负载 载凝血酶(Th)和阿需素(Dox)后, 表面通过一种氨基-颈基交联剂(Sulfo-SMCC)与肿瘤血管靶向肽(CREKA-SH)连接. Copyright C 2020, Springer Nature

Figure 4 (Color online) Nanotherapeutic for combinatorial treatment of vascular occlusion and chemotherapy ${ }^{[36]}$. Chitosan/sodium tripolyphosphate (TPP) nanoparticles were electrostatically loaded with thrombin (Th) and doxorubicin (Dox), and then tumor-targeting peptide (CREKA-SH) was conjungated to the nanoparticle surface via an amine-to-sulfhydryl crosslinker Sulfo-SMCC. Copyright $\mathbb{C}$ 2020, Springer Nature 


\section{5 结论和展望}

纳米材料在癌症治疗领域的变革性应用为开发更 有效的治疗策略开辟了道路，但恶性肿瘤复杂多变的 病理特征对于现有的纳米药物剂型仍是巨大的挑战. 利用纳米载体的多功能优势，设计能够精准递送、响 应控释的“智能”载药体系，并通过同时调控肿瘤组织 中不同成分起到机制层面的联合增效作用，是目前新 型纳米药物研究的重要方向之一.

我们的工作较为系统地探索了利用智能纳米载体 靶向肿瘤微环境不同成分，和递送不同类型药物(小分 子化合物、功能性核酸、抗体和活性蛋白质等)的方 法，证明针对不同肿瘤微环境的特征精准设计递送策 略, 能够有效地提升现有疗法的治疗效果. 而利用纳米 载体在结构设计、功能集成方面的优势，可以实现将 非传统的调控靶点(如肿瘤相关血小板 ${ }^{[34]}$ )或药物引人 抗肿瘤治疗并实现传统疗法增效. 尤其是通过精确组 装的DNA纳米结构 ${ }^{[14]}$ 初步将传统上认为无法静脉注射 的凝血蛋白转化为安全的静脉递送体系，提示了生物 纳米技术的发展有可能启发新的微环境调控和肿瘤治 疗策略.

未来的智能纳米药物研究无疑将向更精准的设计 和更精细的功能方向发展. 如DNA纳米机器人在动物 模型中的成功应用提示的 ${ }^{[14]}$ ，深人理解不同材料在纳 米尺度和超分子层面的理化性质(如自组装行为), 实现 纳米材料的程序化设计和精确可控构筑，是开发能够 在体内执行复杂功能的纳米体系的基础. 鉴于肿瘤的 异质性和个体差异问题仍是现有治疗模式的主要障碍,
将基于纳米体系的功能集成策略与个性化医疗结合, 势必是未来的发展方向之一. 例如，已有学者提出，发 展实时诊断和治疗一体化的智能纳米体系，用于及时 追踪病人对纳米疗法的响应情况、实现更准确的病人 分层, 可能是突破纳米药物临床转化瓶颈的关键 ${ }^{[3,40]}$; 而开发适合执行个性化治疗方案(如个性化肿瘤疫 苗 ${ }^{[41]}$ 或基因治疗 ${ }^{[42]}$ 的纳米技术和载体平台也日益成 为研究的热点. 另一方面, 目前的概念性智能纳米药物 体系相对于传统剂型的复杂性正在对转化研究提出新 的挑战. 这除了要求研究者在纳米载体设计方面更细 致地考虑材料合成的便利性和可重复性、动物模型的 局限性等因素之外，也意味着发展先进的生产、表征 方法用于复杂纳米体系的工业生产和体内外评价对于 纳米医学的未来是至关重要的.

作为在国际上较早提出微环境调控型智能纳米药 物研究方向的课题组之一，本团队的相关工作获得了 国际和国内学术界的广泛关注和认可，并得到科学技 术部纳米重大研究计划和重大国际合作项目，以及国 家自然科学基金委重点项目等的资助。团队近期在 Nature Protocols上受邀发表方法学文章 ${ }^{[6]}$, 从特异性和 非特异性激活两个方面，讨论了微环境响应激活的纳 米药物设计和制备的实验方法学问题; 此外还受邀在 Nature Reviews Materials撰写综述, 系统总结了基于生 物分子自组装肿瘤微环境响应性智能纳米药物体系构 建、抗肿瘤作用原理及挑战展望等关键问题 ${ }^{[43]}$. 我们 的未来工作也将继续追求在系统性理解肿瘤微环境病 理意义的基础上，实现智能纳米药物的精准化、个人 化设计.

\section{参考文献}

1 Anselmo A C, Mitragotri S. Nanoparticles in the clinic. Bioeng Transl Med, 2016, 1: 10-29

2 Anselmo A C, Mitragotri S. Nanoparticles in the clinic: An update. Bioeng Transl Med, 2019, 4: e10143

3 Chen H, Zhang W, Zhu G, et al. Rethinking cancer nanotheranostics. Nat Rev Mater, 2017, 2: 17024

4 Shi J, Kantoff P W, Wooster R, et al. Cancer nanomedicine: Progress, challenges and opportunities. Nat Rev Cancer, 2016, 17: 20-37

5 Quail D F, Joyce J A. Microenvironmental regulation of tumor progression and metastasis. Nat Med, 2013, 19: 1423-1437

6 Zhang Y, Han X, Nie G. Responsive and activable nanomedicines for remodeling the tumor microenvironment. Nat Protoc, 2021, 16: 405-430

7 Zhang Y L, Li S P, Jiang Q, et al. An intelligent DNA nanorobot for tumor vascular occlusion (in Chinese). Chin Sci Bull, 2019, 64: 2625-2632 [张 银龙, 李素萍, 蒋乔, 等. 用于肿瘤血管栓塞治疗的智能型DNA纳米机器人. 科学通报, 2019, 64: 2625-2632]

8 Huang X, Molema G, King S, et al. Tumor infarction in mice by antibody-directed targeting of tissue factor to tumor vasculature. Science, 1997, 275: $547-550$

9 Hu P, Yan J, Sharifi J, et al. Comparison of three different targeted tissue factor fusion proteins for inducing tumor vessel thrombosis. Cancer Res, 2003, 63: 5046-5053

10 Li S, Tian Y, Zhao Y, et al. pHLIP-mediated targeting of truncated tissue factor to tumor vessels causes vascular occlusion and impairs tumor 
growth. Oncotarget, 2015, 6: 23523-23532

11 Nilsson F, Kosmehl H, Zardi L, et al. Targeted delivery of tissue factor to the ED-B domain of fibronectin, a marker of angiogenesis, mediates the infarction of solid tumors in mice. Cancer Res, 2001, 61: 711-716

12 Zhang C, Ni D, Liu Y, et al. Magnesium silicide nanoparticles as a deoxygenation agent for cancer starvation therapy. Nat Nanotechnol, 2017, 12: $378-386$

13 Zhang K, Yang P P, He P P, et al. Peptide-based nanoparticles mimic fibrillogenesis of laminin in tumor vessels for precise embolization. ACS Nano, 2020, 14: 7170-7180

14 Li S, Jiang Q, Liu S, et al. A DNA nanorobot functions as a cancer therapeutic in response to a molecular trigger in vivo. Nat Biotechnol, 2018, 36: 258-264

15 Praetorius F, Kick B, Behler K L, et al. Biotechnological mass production of DNA origami. Nature, 2017, 552: 84-87

16 Valkenburg K C, de Groot A E, Pienta K J. Targeting the tumour stroma to improve cancer therapy. Nat Rev Clin Oncol, 2018, 15: 366-381

17 Thota R, Pauff J M, Berlin J D. Treatment of metastatic pancreatic adenocarcinoma: A review. Oncology, 2014, 28: 70-74

18 Samanta K, Setua S, Kumari S, et al. Gemcitabine combination nano therapies for pancreatic cancer. Pharmaceutics, 2019, 11: 574

19 Ji T, Ding Y, Zhao Y, et al. Peptide assembly integration of fibroblast-targeting and cell-penetration features for enhanced antitumor drug delivery. Adv Mater, 2015, 27: 1865-1873

20 Özdemir B C, Pentcheva-Hoang T, Carstens J L, et al. Depletion of carcinoma-associated fibroblasts and fibrosis induces immunosuppression and accelerates pancreas cancer with reduced survival. Cancer Cell, 2014, 25: 719-734

21 Rhim A D, Oberstein P E, Thomas D H, et al. Stromal elements act to restrain, rather than support, pancreatic ductal adenocarcinoma. Cancer Cell, 2014, 25: 735-747

22 Myllyharju J. Prolyl 4-hydroxylases, key enzymes in the synthesis of collagens and regulation of the response to hypoxia, and their roles as treatment targets. Ann Med, 2008, 40: 402-417

23 Schuster L, Seifert O, Vollmer S, et al. Immunoliposomes for targeted delivery of an antifibrotic drug. Mol Pharm, 2015, 12: 3146-3157

24 Ji T, Lang J, Wang J, et al. Designing liposomes to suppress extracellular matrix expression to enhance drug penetration and pancreatic tumor therapy. ACS Nano, 2017, 11: 8668-8678

$25 \mathrm{Hu} \mathrm{K}$, Miao L, Goodwin T J, et al. Quercetin remodels the tumor microenvironment to improve the permeation, retention, and antitumor effects of nanoparticles. ACS Nano, 2017, 11: 4916-4925

26 Han X, Li Y, Xu Y, et al. Reversal of pancreatic desmoplasia by re-educating stellate cells with a tumour microenvironment-activated nanosystem. Nat Commun, 2018, 9: 3390

27 Nichols J W, Bae Y H. EPR: Evidence and fallacy. J Control Release, 2014, 190: 451-464

28 Nakamura H, Fang J, Jun F, et al. Development of next-generation macromolecular drugs based on the EPR effect: Challenges and pitfalls. Expert Opin Drug Deliver, 2015, 12: 53-64

29 Tahara Y, Yoshikawa T, Sato H, et al. Encapsulation of a nitric oxide donor into a liposome to boost the enhanced permeation and retention (EPR) effect. MedChemComm, 2017, 8: 415-421

30 Liu R, Xiao W, Hu C, et al. Theranostic size-reducible and no donor conjugated gold nanocluster fabricated hyaluronic acid nanoparticle with optimal size for combinational treatment of breast cancer and lung metastasis. J Control Release, 2018, 278: 127-139

31 Parodi A, Quattrocchi N, van de Ven A L, et al. Synthetic nanoparticles functionalized with biomimetic leukocyte membranes possess cell-like functions. Nat Nanotechnol, 2013, 8: 61-68

32 Palomba R, Parodi A, Evangelopoulos M, et al. Biomimetic carriers mimicking leukocyte plasma membrane to increase tumor vasculature permeability. Sci Rep, 2016, 6: 34422

33 Kisucka J, Butterfield C E, Duda D G, et al. Platelets and platelet adhesion support angiogenesis while preventing excessive hemorrhage. Proc Natl Acad Sci USA, 2006, 103: 855-860

34 Li S, Zhang Y, Wang J, et al. Nanoparticle-mediated local depletion of tumour-associated platelets disrupts vascular barriers and augments drug accumulation in tumours. Nat Biomed Eng, 2017, 1: 667-679

35 Liu X, Jiang J, Meng H. Transcytosis-An effective targeting strategy that is complementary to "EPR effect" for pancreatic cancer nano drug delivery. Theranostics, 2019, 9: 8018-8025

36 Li S, Zhang Y, Ho S H, et al. Combination of tumour-infarction therapy and chemotherapy via the co-delivery of doxorubicin and thrombin encapsulated in tumour-targeted nanoparticles. Nat Biomed Eng, 2020, 4: 732-742

37 Dienst A, Grunow A, Unruh M, et al. Specific occlusion of murine and human tumor vasculature by VCAM-1-Targeted recombinant fusion proteins. JNCI-J Natl Cancer Inst, 2005, 97: 733-747

38 Patterson D M, Rustin G J S. Vascular damaging agents. Clin Oncol, 2007, 19: 443-456

39 Seidi K, Jahanban-Esfahlan R, Zarghami N. Tumor rim cells: From resistance to vascular targeting agents to complete tumor ablation. Tumor Biol, 
2017, 39: 1010428317691001

40 Lammers T, Kiessling F, Ashford M, et al. Cancer nanomedicine: Is targeting our target? Nat Rev Mater, 2016, 1: 16069

41 Kuai R, Ochyl L J, Bahjat K S, et al. Designer vaccine nanodiscs for personalized cancer immunotherapy. Nat Mater, 2017, 16: 489-496

42 Kedmi R, Veiga N, Ramishetti S, et al. A modular platform for targeted RNAi therapeutics. Nat Nanotechnol, 2018, 13: 214-219

43 Wang J, Li Y, Nie G. Multifunctional biomolecule nanostructures for cancer therapy. Nat Rev Mater, 2021, 6: 766-783 


\title{
Precisely designed nanotherapeutics for microenvironment- targeted cancer therapy
}

\author{
Jing Wang ${ }^{1}$, Guangjun $\mathrm{Nie}^{1 *}$, Yuliang Zhao ${ }^{1} \&$ Xuesi Chen ${ }^{2 *}$ \\ ${ }^{1}$ CAS Key Laboratory for Biomedical Effects of Nanomaterials \& Nanosafety, National Center for Nanoscience and Technology, Beijing 100190, \\ China; \\ ${ }^{2}$ Changchun Institute of Applied Chemistry, Chinese Academy of Sciences, Changchun 130022, China \\ * Corresponding authors, E-mail: niegj@nanoctr.cn; xschen@ciac.ac.cn
}

Using nanocarrier to deliver anti-cancer drugs has become one of the most active research areas in cancer medicine. Nanocarriers can effectively optimize the solubility, stability and pharmacokinetic properties of traditional drugs, and improve adverse effects by altering their biological distribution profiles. However, clinical evidence indicated that the "first generation" nanomedicines, where drugs were passively delivered by a nanosized carrier, were often not efficient enough against the heterogeneity and complexity of tumors. Therefore "smart" designs to synergistically improve delivery and therapeutic efficiency via the application of multiple functional elements have attracted much interest.

The emerging concept of tumor microenvironment regulation has greatly advanced the development of "smart" nanotherapeutics. As therapeutic or drug delivery targets, microenvironmental components such as tumor stroma or vasculature are genetically more stable than tumor cells, and microenvironment-targeted delivery can also facilitate the bypassing of some biological barriers. Our group's research demonstrated that, rational exploitment of intrinsic material and multifunctional advantages of nanostructure-based drug carriers might prove critical for the development of novel anticancer strategies. In recent years, our group has systematically investigated both targeting and regulation strategies based on pathological characteristics of diverse microenvironmental components, achieving a series of innovative therapeutic solutions involving tumor vascular-specific embolization, tumor stromal microenvironment remodeling, or selective clearance of tumor-associated platelet through precisely designed nanotherapeutics. This report briefly reviews the representative results among them and comments on the future directions of microenvironment-modulated nanomedicines.

Examples of our recent advances include: (1) Using self-assembled DNA origami nanorobots, we have developed a novel approach to safely deliver thrombin, a potent coagulant, via intravenous administration. The highly programmable supramolecular behaviors of nucleic acids allowed the protein to be accurately collocated inside the tube-shaped nanorobot without risking to be non-specifically exposed during the transport in the bloodstream. Once arrived at the tumor microenvironment, the nanorobot could be selectively "unlocked" by a tumor-specific endothelial marker via molecular recognition. This approach for the first time transformed thrombin, a protein that was previously thought unsuitable for intravenous injection to a biosafe and effective agent for tumor-specific blood vessel occlusion. (2) A multifunctional nanostructure has been developed to re-model the tumor stroma for enhanced chemotherapy. Depleting the dense and fibrotic tumor stroma reportedly enhanced intratumoral drug penetration but in some cases might disrupt tissue homeostasis leading to tumor progression or metastasis. Using a polymeric nanoparticle that selectively reversed its surface charge in the slightly acidic tumor microenvironment, we effectively delivered anti-fibrotic and stromal cell-inhibiting drugs into tumor stromal cells through tumor-triggered cellular uptake. This nanotherapeutic was shown to significantly induce quiescence of stromal cells, reducing their extracellular matrix production and pro-tumor signaling to enhance the efficacy of co-administrated chemotherapy. (3) A novel strategy to enhance nanoparticle delivery across the vascular endothelial barrier has been proposed via localized depletion of platelets, whose presence and activation in the tumor microenvironment helped to maintain the endothelial integrity of tumor vasculature. Co-delivery of anti-platelet antibodies with chemotherapeutic drug through a nanoparticle system capable of enzyme-responsive, multiple-step drug release effectively induced endothelial damage in tumor tissues, leading to enhanced extravasation of the nanoparticleencapsulated chemotherapeutic. (4) Using a tumor-targeted chitosan nanoparticle to co-deliver thrombin and doxorubicin we have achieved further improved anti-tumor efficacy of vascular occlusion therapy. While rim cells in tumor tissues were often less sensitive to anti-vascular treatments, the co-administration of chemotherapeutic drug allowed us to more efficiently eradicate these cells and prevent recurrence, demonstrating the potential of multifunctional nanotherapeutics in overcoming tumor heterogeneity.

In summary, our work has demonstrated that based on specific pathological characteristics of different types of tumors, it is possible to precisely construct multifunctional nanocarriers for drug delivery and microenvironment modulation to achieve optimal efficacy. The next generation of "smart" nanotherapeutics will certainly aim at more programmable material design and more sophisticated in vivo actions, and our effort will continuously be dedicated to understanding the tumor microenvironment in order to enable personalized microenvironment-targeted nanomedicine.

tumor microenvironment, nanomedicine, targeted delivery, nanorobot, biological barriers 